\title{
The "middle archive" exploring the practical and theoretical implications of a new concept in Sweden
}

\author{
Ann-Sofie Klareld
}

Department of Archives and Computer Science, Mid Sweden University, Härnösand, Sweden

\begin{abstract}
Purpose - The purpose of this paper is to study how the concept "middle archive" is related to the Swedish archival theory and practice, by exploring its background and its practical and theoretical implications. The overarching aim is to increase the understanding of the interrelations between the archival theory and practice, with a special focus on changes occurring in the digital environment in Sweden.

Design/methodology/approach - The paper is based on a qualitative study of texts produced between 2010 and 2013, which were read and analyzed iteratively. The research design and analysis is inspired by Dryden (2014) who recommends taking the context into account. The three types of digital repository developed by Millar (2010) are used as a comparison to further extend the understanding of the concept of the "middle archive".

Findings - The findings indicate that the "middle archive" was introduced as a solution to practical problems of managing digital records, and that there is a need to further discuss how the term relates to existing theoretical, legal and administrative contexts.

Research limitations/implications - The study is limited to contemporary Sweden. The researcher did not follow the discussions and drafts which contributed to the development of the final definitions of the "middle archive".

Originality/value - The study contributes to the research and development of archival concepts, with a special focus on recent developments in Sweden. The paper highlights some of the challenges relating to archives and records in the context of e- government development.
\end{abstract}

Keywords Sweden, Recordkeeping, Digital archives, Archival terminology, E-Archives,

Middle archive

Paper type Research paper

\section{Introduction}

In Sweden, the rules and regulations on records and archives are format-independent, yet previous research indicates that practices have changed significantly during the period of e-government development (Kallberg, 2013; Svärd, 2011). The National

Funding and collaborative partners are crucial to promote purposeful research. The author would like to thank the County Administrative Board in Västernorrland and Härnösand Municipality for funding the Good Information Governance project (GoInfo) together with Mid Sweden University. The author is also grateful to the Regulatory Network Västernorrland and the National Archives of Sweden for participating in, and contributing to, the project.

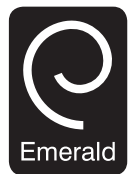

Records Management Journa Vol. 25 No. 2, 2015 pp. $149-165$ c Emerald Group Publishing Limited DOI 10.1108/RMJ-12-2014-0047 
Archives have concluded that a vast majority of state public agencies lack a strategy for management and preservation of digital records (Riksarkivet, 2010b). This can prevent citizens from accessing official information. Incongruent information systems complicate the re-use of information, risking the limitation of "[...] the function of the archives as an integral part of the information resources [...]" (Svärd, 2011, p. 113). To
address these challenges, the Swedish government has given a newly created agency, the State Service Centre (SSC), in cooperation with the National Archives, the task to create, a national common e-archive service for public agencies [Sweden (Näringsdepartementet), 2014]. A pre-study report written prior to the decision had concluded that substantial cost savings could be made through this arrangement (Aspenfjäll, 2013). This type of e-archive is currently often called a "middle archive".

The challenges of the digital era are not unique to Sweden. Public agencies all over the world are increasingly shifting from paper-based to digital procedures. As a consequence, scholars and practitioners are re-evaluating traditional recommendations about creating, managing, preserving and providing access to records. If the benefits of e-governance are to be realized to their full potential, it is necessary to simultaneously revise legal, administrative and theoretical frameworks. The archival community might need to rethink some of their fundamental "truths", which have been derived from traditional procedures. This affects theory as well as practice. David Bearman has argued that "[...] archivists have elevated pragmatic responses to the nature of physical things to the level of ideology" (Bearman, 1996, p. 197). The findings of this study indicate that practices developed in the "paper world" have influenced the definitions of the concept of the (digital) "middle archive" in Sweden.

The paper takes a closer look at how the concept "middle archive" is related to the Swedish archival theory and practice, by exploring the background to the concept and its practical and theoretical implications. The overarching aim is to increase the understanding of the interrelations between the archival theory and practice, with a special focus on changes occurring in the digital environment in Sweden.

The concept of the "middle archive" was chosen because it is closely connected with the challenges of information governance in the digital environment, which is currently under discussion in Swedish public agencies. Three definitions of the concept are explored, to understand how it has emerged and developed, how it relates to theory and practice and how the concept is related to existing legal and administrative frameworks. The concept is also compared to the three types of digital repository discussed by Millar, and her list of requirements that a digital repository should meet (Millar, 2010).

\section{Background}

The Swedish holistic view of archives differs from that of most other countries in that it requires proactive information governance for official records. Sweden also has a far-reaching freedom of information legislation (Sweden, 1949, p. 105, SFS). To make the paper more accessible to an international audience, the legal/theoretical and the administrative/practical background are explained here in relation to the concept of the "middle archive".

Since 1766, the Swedish constitution gives citizens free access to public records. The general rule is that all records are official from the point of creation, or receipt. The constitution is further supported by the Archives Act, which declares that public agencies' archives are part of the national cultural heritage. Both "archive" and "official 
record" are format-independent concepts. According to the Archives Act $\S 3$, the archives of an authority consist of the official records created through its activities. They are to be preserved, kept in order and handled in ways that ensure:

- The right of free access to public records;

- The information requirements of the public jurisdiction and administrations; and

- Research requirements (Sweden, 1990, p. 782, SFS) [Translation by (Hörnfeldt, 1998)].

New concept in Sweden

According to the Freedom of the Press Act an "official record" is "any written or pictorial matter or recording which may be read, listened to, or otherwise comprehended only using technical aids"(Sweden, 1949, p. 105, SFS).

Although the same rules apply to records and archives, there is a legislative demand to clearly distinguish between the records of active and inactive cases, for efficiency and legal reasons. The Archive Ordinance states that closed cases should be archived (Sweden, 1991, p. 446, SFS). This is because the citizens should be able to verify that cases are handled properly. To ensure this, each state public agency must annually provide the Chancellor of Justice with a list of active cases from the previous year, adding explanations as to why they are still active (Sweden, 2007, p. 515, SFS). It is important that closed cases are archived in a way that makes it possible to see how they were handled and which information decisions were based on, this, for example, to be able to make an appeal.

In a paper environment, the required separation of active and closed cases is usually ensured by physical relocation - active cases are kept in the office and inactive cases are moved to a "near archive", a separate room close by, permitting easy access. When the records are no longer regularly needed, they are moved again, either to a central archive (often located in the basement), or to an archival authority. This means that in practice, there is a difference between how "active", "semi-active" and "archival" records are treated. The "archive" is often perceived to consist of records kept in a separate storeroom, and delivery to an archival authority is primarily considered when there is limited physical space. Digital records do not take up office space, but it is unclear how to archive closed cases in the digital environment and ensure long-term preservation. These issues are currently discussed at public agencies and a "middle archive" is sometimes put forward as the solution.

In Sweden, the public agencies of the state and those of the counties and municipalities are supervised by different archival authorities: the National Archives is responsible for state public agencies, but has no authority over counties and municipalities. Each county and municipality have their own archival authority, however, many of them follow the National Archives guidelines. For a more comprehensive description, see Kallberg (2012) and Geijer et al. (2013). The archival authorities oversee the public agencies, ensuring that they preserve and make their respective archives accessible. The Archives Act states that public agencies remain fully responsible for their records until formal transfer to an archival authority (Sweden, 1990, p. 782, SFS). There is no pre-defined time limit for this, which is why some public agencies hold centuries-old information resources. This is one reason why public agencies and municipalities need a "middle archive", or a digital repository, for their records, prior to transfer to their respective archival authorities. 
The answers to the questions of where information is located, how it is to be transferred, who is responsible and what/which information should be archived, can to a certain extent be found in the Swedish legislation. The practical implementations are, however, still both unclear and inconsistent. Regular disposal is rare, and large quantities of information reside in business systems, e-mail systems and Web servers (Larsson, 2012; Riksarkivet, 2010b). Note that the term disposal, or disposition, is sometimes used as equivalent to destruction (Hörnfeldt, 1998). In this paper, it is, however, used according to ISO 15489, meaning: "a range of processes associated with implementing records retention, destruction or transfer decisions which are documented in disposition authorities or other instruments" (Swedish Standards Institute, 2001, p. 7).

The term "middle archive" and "middle archiving" has previously been used to describe procedures which differ fundamentally from Swedish principles (Geijer et al., 2013; Gränström, 2000; Jörwall et al., 2012). In the book The Archives Act, Background and Comments, Claes Gränström, former Deputy Director General at the National Archives, translates the word "mellanarkiv" (middle archive) to "intermediate archive" and describes it as a certain type of institution, where destruction and description is carried out. Gränström states that "middle archives" are mostly found in Anglophone countries, where the concept of the archive differs from the Swedish, as only the records transferred to an archival institution are considered to be archival and that this implies less fidelity to the original order (Gränström, 2000). (The concept of provenance is still debated internationally. In my opinion, there is room for further discussion about how it applies in the context of e-governance.) The term "institution for middle archiving" is likewise used by Geijer $e t$ al. in a discussion concerning the principle of provenance, to describe archival procedures "commonly used abroad", where archives are arranged, destroyed and described before transferal to an archival institution. (Geijer et al., 2013)

Despite this, "middle archive" is currently used when referring to a digital storage function for semi-active records. This makes the question of whether the current use of the concept reflects any changes to the archival theory and practice in Sweden a relevant question to ask. "Middle archive" is also used in the paper environment, although it is in a digital setting that attempts have been made to define and explain it. When referring to a "middle archive" in this paper, a digital archive is intended, if not stated otherwise.

\section{Research methodology}

Previous research shows that the e-government development affects mandates and responsibilities relating to archival records (Runardotter et al., 2011). One of the most recent definitions of the "middle archive" is an outcome of e-Archive and e-Diarium (eARD), a collaborative project connected to e-government development, which is likely to affect future archival procedures in Sweden. This because its results - common specifications for transferring information between any and all information technology systems - improves the ability to transfer digital records from a business system to an e-archive (Riksarkivet, 2014a). Defining a concept can be a way for those who promulgate the definition to exercise power. This makes it relevant to study how new concepts influence theory and practice.

The research questions addressed in the paper are:

$R Q 1$. How does the concept "middle archive" relate to existing archival theory and practice? 
RQ2. Is the concept comparable to any of the three types of digital repository discussed by Millar? (Millar, 2010)

The method chosen for this study of the "middle archive" is concept analysis. Concepts are mental constructions which help us create order and meaning and make it possible to communicate with others (Friberg, 2012). When studying current development of archival concepts, the background and progression become important: "[...] it is the process of construction that is interesting rather than the constructs themselves" (Czarniawska, 1997, p. 63). Qualitative method was chosen because it is suitable for interpretative studies of new concepts and "[...] permits a more flexible understanding of complex and evolving social constructs" (Gorman and Clayton, 2004, p. 14). The research design and analysis is inspired by Dryden who recommends taking context into account (Dryden, 2004). Millar's three types of digital repository (Millar, 2010) are used as a comparison to further extend the understanding of the concept. The study draws on data in the form of formal texts from three different sources, in which there are definitions of the concept. The material was read and analyzed iteratively. Selected parts are reproduced in Table I.

The decision to narrow the focus of the concept analysis to formal texts and not include working drafts was made with the intention of studying how outcomes of different projects and agencies have shaped the concept. Each definition of the concept is then compared with Millar's definition of a digital repository and list of requirements, with the intention to further explore the relations between theory and practice. It is possible other thoughts and definitions could be obtained by also studying drafts and conducting interviews. This is, however, outside the scope of this study.

\section{Theoretical framework}

The word "archive" is multifaceted and can have many dynamics; legal, administrative, technical, scientific, etc. As Sweden has a long history of a holistic, format-independent approach, it could be expected that an "e-archive" would be regarded as essentially the same as an archive, only in another format. But although different suggestions have been developed, see, for example, (Riksarkivet, 2008) and (Riksarkivet eARD, 2013c), the concept "e-archive" still lacks a clear definition.

Dryden argues that archival terminology is often "fuzzy", as even concepts that have been around for a long time, for example, "provenance", do not have a clear definition in international standards (Dryden, 2004). The development of new formats is one explanation for the ambiguity: "Archivists over the last fifteen years have been forced by their immediate contact with changes in technological conditions to reconsider their concepts" (McKemmish, 2005, p. 14). This may cause problems of both practical and theoretical nature. "The use of computers in both creating and maintaining records has brought almost all concepts in archival theory into question" (Ridener, 2009, pp. 102-103). It was concluded at the Stockholm Conference on Archival Science and the Concept of Record in 1996 that a more common understanding of archival terminology is needed, as "[...] it is difficult to discuss archival issues, when different archival concepts may be identified by the same term" (Yoos, 1998, p. 147). Ewald has discussed this dilemma in a Swedish context, and similarly argues that clearer definitions are required. She uses the concept "creating agency" as an example; it lacks a clear definition and can have a different meaning, depending on the administrative and juridical context (Ewald, 1997). Research on how concepts relate to the existing archival

New concept in Sweden 


Source Definition Date

Hanteringen av arkiv frän myndigheter som avvecklas [The management of archives from discontinued agencies] (Riksarkivet, 2010a, p. 15)
Ordlista Sambruk [Sambruk Glossary] (Sambruk, 2011b, p. 8)

Begreppsista eARD [eARD Glossary] (Riksarkivet eARD, 2013a)

\section{Table I.}

Three definitions of "middle archive" 2010-2013 (my translation)
"According to the first model the agencies transfer their records to the middle archive function as soon as they are no longer needed in the business, but keep the substantive responsibility for 10-20 years, or more if it is required with respect to secrecy etc. Only then is a delivery in the sense of the Archives Act made, which means the full responsibility of the records passes to the National Archives. During the time in the middle archive function the agency examines the disclosure of records. The agency also addresses deficiencies in the condition of the records and investigates destruction. Destruction is carried out by the middle archive function"

According to the second model the full responsibility is directly passed to the National Archives, which within the frame of the middle archive function investigates and executes destruction and takes other needed measures with the records before they are transferred to long term preservation" Middle archive/near archive: "Sooner or later some information, for example older contracts, will no longer be needed in the daily work of the business. One can however consider it to still be of use, and therefore not ready to send to final archiving. A middle archive is a system for preservation for information which is transferred from a business system, but is still available for the business"

(Words in italics indicate that these are included in the Glossary)

Definition: "An archive solution where an archival authority has not yet assumed responsibility for the archived records" Explanation: "A middle archive is a system for preservation for such information that is transferred from a business system, but is still available to the business. In this solution the business keeps its responsibility for the records until the business needs have subsided"
31 August 2010

17 October 2011

14 January 2013 
theory and practice helps to develop the theoretical framework. Dryden concludes that more research is needed on the subject and that it is particularly important to study how new concepts are created:

Formal definitions that occur in glossaries are taken as authoritative and are frequently incorporated into many other documents. But what about concepts that are emerging as the profession grapples with the challenges of electronic records, or our understanding of appraisal? This raises the question of how terminology is established before definitions are formally recorded in glossaries. When new terms or concepts are developed, they tend to be defined by those who first discuss them. As the discussion widens, and the concepts evolve, the definitions or understandings tend to shift as well, and begin to appear beyond the writings of those who initiated the discussion. If, as seems likely, there is not complete agreement about the definition of a term, different definitions may appear in different places, thus perpetuating the uncertainty about their meanings (Dryden, 2004, p. 150).

Initiatives to collect concepts and definitions relevant to archivists and records managers include: Glossary for Archivists, Manuscripts Curators and Records Managers (Bellardo and Bellardo, 1992), Nordic Archive Terminology (Ásgeirsson et al., 2003), A Glossary of Archival and Records Terminology (Pearce-Moses and Baty, 2005), International Council on Archives (ICA), Multilingual Archival Terminology (MAT) (International Council on Archives, 2014), Glossary of Records and Information Management Terms (ARMA International, 2014), Archives \& Recordkeeping Glossary (National Archives of Australia, 2014) and Dictionary of Archival Terminology (Walne, 2014).

\section{Digital repositories}

One way to understand the "middle archive" is as a digital repository. The $M A T$ defines "repository" as an "[a]gency or programme responsible for selecting, acquiring and preserving archives, making them available, and approving destruction of other records." It is noteworthy that the Swedish equivalent according to $M A T$ is "arkivlokal", literally translated as "archival storeroom" (International Council on Archives, 2014). "Digital repository" is not included in any of the glossaries searched.

Millar has discussed strengths and weaknesses of three types of digital repositories, based on the OAIS model:

(1) Centralized institutions;

(2) Decentralized or third-party institutions; and

(3) Networked repositories.

An Open Archival Information System (OAIS) consists of:

[...] an organization, which may be part of a larger organization, of people and systems, that has accepted the responsibility to preserve information and make it available for a Designated Community (Consultative Committee for Space Data Systems [CCSDS] 2012, p. 13). According to Millar, the agency responsible for an OAIS, which acquires, preserves and provides access to digital records and archives, is often called a "digital archival repository" (Millar, 2010, p. 220).

Millar discusses the pros and cons of each type of repository, related to issues such as control, risk management, resources, service, service providers, sustainability, quality, technology, infrastructure, cost sharing, collaboration and coordination. She also lists 
ten requirements that the agency responsible should meet, for example, ensuring that the archives are managed in accordance with legal requirements, establishing effective preservation strategies and adhering to standards for metadata management (Millar, 2010).

Millar seems to assume that an archival institution is responsible for the digital repository. In the Swedish context, however, repositories are needed before the records are formally transferred to an archival authority. Public agencies cannot waive the responsibility for their records, except after transfer to the archival authority, and they remain responsible even if the archive is, in practice, managed by another agency or a private company.

\section{The "middle archive": exploring the development of the concept}

The Nordic Archive Terminology (NAT) shows that the term "middle archive" exists in Danish, Finnish, Icelandic and Norwegian. In English, the concept is explained by the two terms: "intermediate storage": "The storage of semi-current records in a records centre pending their ultimate disposal", and "records centre": "A facility for the low-cost storage, maintenance and reference use of semi current records pending their ultimate disposition [...] also referred to as intermediate storage or limbo" (Ásgeirsson et al., 2003). The Glossary of Archival and Records Terminology does not include "intermediate storage". "Records centre" is defined as: "A facility used for low-cost storage of inactive and semi current records before those records are destroyed or transferred to an archives" (Pearce-Moses and Baty, 2005). The MAT includes "intermediate archive" or "intermediate storage" and "records centre" with the same definitions as the NAT (International Council on Archives, 2014). The Glossary of Records and Information Management Terms does not include "intermediate storage". "Records center" is defined as: "An area for lower-cost storage, maintenance, and reference use of semi active records pending their ultimate disposition" (ARMA International, 2014).

To understand the implementation of the term "middle archive" in Sweden, it is necessary to appreciate the context in which it originated. In 1991, an official report from the Swedish Government, The State Archives Repositories: A Development Plan by 2000, stated that technology-dependent records had been increasing faster than paper records since the mid-1980s (Arkivdepåkommittén, 1991). A National Archives survey in 2010 showed that only about 5 per cent of the state public agencies had a strategy in place for managing their digital records (Riksarkivet, 2010b). Larsson considers it likely that there are records which cannot be accessed due to obsolete formats and outdated software, and, what is more, that this is a growing problem (Larsson, 2012).

Digital records need more active management than records on paper or microfilm, and should be reviewed on a regular basis. This leads to questions concerning technology, mandates and responsibilities. The concept "middle archive" can be seen as a practical solution for addressing these issues.

Several different definitions of the concept can be found, which implies a lack of clarity about its meaning. Stockholm County Regional Archives explains their "middle archive" for medical records as:

- an "e-archive", where the information "is not archived in the true sense of the word", as the archival authority has not yet assumed ownership of the material;

- a database, where semi-active records are stored in a format that is suitable for long-term preservation; and 
- a service, which collects information from the middle archive and from a medical records system, and presents this as one image to the user through an interface (Öberg, 2011, my translation).

R7, an e-archive collaboration, today including nine counties, describes their "middle archive" as "comparable to a physical archive, where you can search by yourself in material that you are certified to view" (my translation). It should be used when an old system is to be terminated and the organization still needs access to the information (R7, 2014). "Middle archive" is also used as a term in the paper context:Flen municipality describes it as a storeroom where paper records are kept until they are to be destroyed (Flen Municipality, 2013).

The differences are examples of the phenomenon Dryden highlights: concepts are defined differently by different actors (Dryden, 2004). Although several definitions can be found, this study is limited to taking a closer look at the three definitions presented below in Table I. These were selected because they originate from three agencies which all have nationwide influence on archival development: the National Archives, the Sambruk project and the eARD project. Sambruk, The Swedish Association of Municipalities for Joint Development of e-Services, was a cooperation initiative with the overall purpose to:

[...] create a foundation for an effective development programme, comprising both the technical and functional aspects of e-services, as well as the need for re-engineering of the municipalities' internal business processes (Föreningen Sambruk, 2008).

eARD was initiated by the eGovernment Delegation, a committee under the Ministry of Industry, and implemented by the National Archives. The aim was to develop common specifications for transferring information between business systems and e-archives. The vision of the project was "It should be easy to retrieve, reuse, and transfer information held by public agencies to the archive regardless of where and how the information is stored" (Riksarkivet, 2014a).

(More information is available at the Web page of the respective project: the National Archives [Riksarkivet, 2014c]; Sambruk [Sambruk, 2014]; eARD [Riksarkivet, 2014b]).

\section{The National Archives}

The first definition of "middle archive" is found in a National Archives' report to the government offices, addressing the issue of archives from discontinued agencies (Riksarkivet, 2010a). This definition is the only one that includes alternative models the "middle archive" is either owned by the creating agency, or by the archival authority. In both cases, destruction is carried out by the "middle archive function". The first model suggests a time limit of 10-20 years or more, before an archival authority assumes responsibility.

The report emphasizes the practical problems of transferring records from the creating agency to the archival authority. One example is that disposal plans are not always in place, which means that the archival authority becomes responsible for carrying this out. Possible solutions suggested in the report include increasing the frequency of regular inspections by the National Archives and, thus, ensuring that regular destruction is carried out, legislating the public agencies' obligations to create destruction schemas and giving the National Archives the mandate to investigate destruction for the agencies, which is described as the most proactive approach. As 
disposal issues should ideally already be determined in the implementation phase of a new business or system, a complementary measure suggested is that the National Archives will not accept records lacking a disposal plan (Riksarkivet, 2010a). The report argues that the possibility of creating a form of joint "middle archive function" for the whole state public administration should be investigated, as it could facilitate the management and preservation of public agencies' archives. This type of solution is said to be suitable as a common support function for the government administration (Riksarkivet, 2010a). In 2014, the government delegated authority to the SSC, a public agency responsible for providing administrative services to other public agencies, to develop and implement this type of solution with support from the National Archives [Sweden (Näringsdepartementet), 2014].

\section{Sambruk}

The second definition is an outcome of the Sambruk project. Here, "middle archive" is equated with "near archive"; information not needed in the daily business is transferred to the "middle archive" until it is ready for "final archiving". Though the Sambruk Glossary (Sambruk, 2011b) is published online as a supplement to the final report, it declares that the terms are not formally established but that the glossary is limited to explaining the use of terms in the context of the project (Sambruk, 2011b).

The report eSociety and the Archive: Electronic Preservation Phase 2 further explains the concept as a possible technical solution which can be integrated into a system for preservation and then advantageously be controlled through detailed technical requirements upon delivery. It is emphasized that when the records are transferred to the "middle archive", functionalities from the business system will not follow. The records will not be mutable, but will be preserved as they are received. Practical recommendations included in the report are that the information should only be packaged once, so that later transfer to a system for preservation can be made without difficulties and automatic destruction should be used, due to the diversity of disposition times (Sambruk, 2011a).

The report explains the difference between "information owner" and "system owner", a difference perhaps more self-evident in the paper environment, but which can be problematic in relation to digital records. It is emphasized that the creating agency owns the information, and remains responsible even if the system where the records reside is owned by someone else. The archival authority will not own the information until it is transferred to a "final archive" (Sambruk, 2011a).

\section{$e A R D$}

The recently finished eARD project developed common specifications, abbreviated as "förvaltningsgemensamma specifikationer (FGS)", for transferring information between any and all systems. eARD was initiated in 2009 by the eGovernment Delegation, a committee under the Ministry of Industry, responsible for coordinating eGovernment development. The delegation consists of the 16 most information-intensive state public agencies and the Swedish Association of Local Authorities and Regions, Swedish Association of Local Authorities and Regions (SALAR) (eGovernment Delegation, 2013). The first outcome of the eARD project was a list of concepts with 109 terms in total, among them "middle archive". Six of the terms were said to be in need of further investigation by the National Archives: "archive 
system", "e-archive”, "e-archiving”, "information type”, "system for preservation” and "system for long term information supply" (Riksarkivet eARD, 2013a).

eARD's definition of "middle archive" is the shortest included in this study. It centers more on delegating mandates and responsibilities than on the technical aspects, which is noteworthy, given that eARD focused on technical specifications for transfer of information between systems. According to the FGS Package Structure for E-Archives, published on the same day as the list of concepts, many "e-archives" manage both a "middle archive" and a "final archive". The status of an Archival Information Package can easily be changed from "middle archived" to "finally archived". It is emphasized that this type of procedure is not addressed in this report, only "[...] the condition when information is physically transferred from one system to another" (Riksarkivet eARD, 2013b, p. 30, my translation). It is not mentioned anywhere else in the analyzed documents that an "e-archive" can consist of both a "middle archive" and a "final archive". Elsewhere, these have always been described as different entities with different ownership and responsibilities attached.

The eARD report Guidelines and Functional Requirements argues that a "middle archive" is a solution which can facilitate the process of creating a uniform information structure early on. It is further described as a way to capture information as a resource and ensure preservation of information from obsolete systems. The business will then be able to terminate old systems but still have access to the information (Riksarkivet eARD, 2013c).

\section{Discussion}

All of the analyzed definitions describe the "middle archive" as a solution for semi-active records, organizationally placed between the creating agency and the archival authority. The concept can be illustrated as in Figure 1.

Although the definitions have much in common, they emphasize different aspects of the concept. The National Archives' definition includes two possible solutions, and the report highlights destruction as a crucial issue, and an argument for setting up a "middle archive”. It also suggests a time limit (Riksarkivet, 2010a). Neither alternatives nor time limits are evident in the other definitions.

None of the reports explains the "middle archive" in relation to the Swedish concept of the archive, and the issues addressed and discussed in the reports are of a practical rather than a theoretical nature. It is also notable that all definitions use "records" or "information" to describe what should be archived, not "cases", thereby not emphasizing that the context of the records belonging to the same case need to remain intact in the archive. The legislative demand to archive closed cases in an e-governance context can mean that information from several different systems needs to be preserved jointly. This has not been clearly considered in relation to the "middle archive" in these definitions. The Sambruk report alone explains that functionality of business systems will not
New concept in Sweden

159

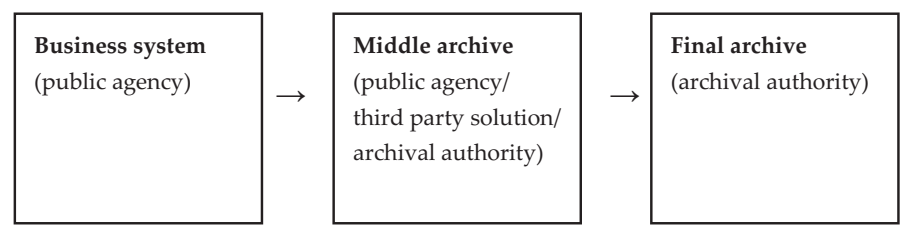

Figure 1.

The organizational placement of the "middle archive" 
follow into the "middle archive". There is a need to further develop the concept and practical solutions for the "middle archive", so that provenance can be ensured in some other way.

The second version of the National Archives' definition puts more emphasis on the technical aspects than Sambruk and eARD does. The "middle archive", as it is described by all three agencies, however, resembles the practical procedures used in the paper environment to a large extent, although the holistic concept of the archive, formalized in the Archives Act, does not distinguish between active, semi-active and archival records. Instead, records become archival, in a way, at the point of creation. Danielson and Crozier claim that the Swedish holistic view of archives "[...] goes hand in hand with a strong tendency to perceive archives as organic wholes and to emphasize the link between older and current parts of an archive" (Danielson and Crozier, 2004, p. 164). When the Swedish tax authority developed their e-archive solution, they stated that it should meet the requirement to first archive cases, and then administer them, thereby emphasizing the importance of proactive information governance to the benefit of the public agencies as well as the citizens. Making the records archival at the point of creation was seen as a prerequisite to fulfill the legal requirements (Standéus, 2007). However, the "middle archive" as presented in the three definitions under discussion, is a way of managing "semi-active" information, clearly separating this from "active" and "archival" information.

Swedish public agencies cannot waive the responsibility for their official records. As both Sambruk's and the National Archives' reports state that the "middle archive function" will carry out some tasks, for example, destruction (Riksarkivet, 2010a; Sambruk, 2011a), there is a need to further discuss issues related to the division of responsibility between the creating agency and the service provider. Clear formal agreements are required if the holistic concept of the archive is to be maintained. Destruction of official records should be considered in relation to the fact that they are part of cultural heritage (Sweden, 1990, p. 782, SFS). Gränström emphasizes the importance of making sure the destruction of records held in one information system does not affect the understanding of records in another system (Gränström, 2004). This is not discussed in any of the texts analyzed.

In the texts that were analyzed, the concept of the "middle archive" is mainly related to practical issues from the perspective of public administration. All definitions focus more on business needs, such as reducing costs by terminating obsolete systems, than on the needs of citizens, public jurisdiction and future research. The National Archives presents the concept as a solution to the problem of public agencies transferring records that are not ready for final archiving. Sambruk equates "middle archive" with "near archive", enhancing the connection to existing paper procedures. The eARD Project defines "middle archive" in a way that emphasizes the division of responsibility between creating agencies and public archival authorities. The need for continuous archiving is not discussed, only the transfer of information from business systems, primarily in relation to cost and efficiency reasons. Furthermore, ensuring the preservation of context across different business systems does not appear to have been considered in any of the definitions.

Millar discusses digital repositories from a Canadian perspective, where digital repositories contain archival records in the custody of an archival institution. In the Swedish context, it is also relevant to discuss recordkeeping, including records still 
active in the creating/receiving agency, as according to the legislation, active records are part of the national cultural heritage and citizens have the right to access these records from the point of their creation. The concept of the "middle archive" is comparable to each type of digital repository developed by Millar. The considerations of pros and cons which Millar discusses is, however, lacking in the glossaries and reports analyzed in the paper. Though the National Archives discusses two models, the report does not elaborate much on the pros and cons of either alternative.

Worth mentioning in relation to the discussion about archives and recordkeeping in the digital era is the European Union Directive to promote reuse of Public Sector Information (European Parliament and the Council, 2003). The Swedish Public Sector Information-investigation (PSI)-investigation discusses how to implement this directive in Sweden. One suggestion is to make active, semi-active and archival records of all state public agencies searchable through a single interface for which the National Archives will be responsible (PSI-utredningen, 2014). The interface would facilitate searchability, but would not make the archival authority responsible for the content or the preservation of the records. Instead these could be kept in a "middle archive". However, it has been suggested that the National Archives should be given the task to issue regulations about how public agencies should schedule the records that are available for reuse.

The results of this study support Bearman's claim that practical procedures originating in the paper environment can live on in the digital environment, in this case, even if they are not adapted to meet the demands of e-government. Incorporation of new concepts and solutions to practical problems need to be discussed by the archival and recordkeeping communities and related to existing administrative, legal and theoretical frameworks before being implemented. Otherwise, there is a risk that inconsistencies are unintentionally built into the procedures, something that will affect the archives of the future. In the words of Sue McKemmish:

[...] in developing and implementing our models, systems, standards, policies, strategies, and schemas, we are not fashioning and using neutral or impartial tools, we are building structures of remembering and forgetting. (McKemmish, 2001, p. 356)

\section{Concluding remarks}

The research questions addressed in this paper were:

$R Q 1$. How does the concept "middle archive" relate to existing archival theory and practice?

$R Q 2$. Is the concept comparable to any of the three types of digital repository discussed by Millar? (Millar, 2010)

In the definitions analyzed, the concept of the "middle archive" is not explicitly related to the existing archival theory and legal regulations. The principle of public access to official records is not given the amount of space that could have been expected, given that it is a cornerstone of Swedish legislation. As currently defined, the new concept "middle archive" may not be optimal in the Swedish context, as it can be interpreted to imply that the age and physical location of records is connected to their status as part of the official archives and national cultural heritage. Swedish legal and administrative principles are built on the view that the creating agency and the archival authority have 
the same basic responsibilities for the records, both with respect to preservation and access. Therefore, Millar's list of requirements that a digital repository should meet would also be relevant considerations when discussing and implementing a "middle archive" solution.

\section{References}

Arkivdepåkommittén (1991), Statens arkivdepåer: en utvecklingsplan till år 2000: betänkande [The State Archives Repositories: A Development Plan by 2000: Report], Allmänna förlaget, Stockholm.

ARMA International (2014), "Glossary of records and information management terms", available at: http://archive.arma.org/standards/glossaryw2/index.cfm?id_term=152 (accessed 11 April 2014).

Ásgeirsson, Ó., Eriksen, A., Lindh, B., Marthinsen, J.H. and Pussinen, V.-M. (2003), "NAT - nordic archive terminology", available at: www.narc.fi/nat/ (accessed 28 March 2014).

Aspenfjäll, J. (2013), Förstudie Statens servicecenter e-arkiv och e-diarium [Pre Study State Service Center e-archive and e-diarium], eBuilder, Kista.

Bearman, D. (1996), "Item level control and electronic recordkeeping", Cultural Heritage Informatics Quarterly, Vol. 10 No. 3, pp. 195-245.

Bellardo, L. and Bellardo, L.L. (1992), “A glossary for archivists, manuscripts curators, and records managers”, The American Archivist, Vol. 37 No. 3, pp. 415-433.

Consultative Committee for Space Data Systems (CCSDS) (2012), Reference Model for an Open Archival Information System (OAIS), Washington.

Czarniawska, B. (1997), Narrating the Organization: Dramas of Institutional Identity, University of Chicago Press, Chicago, IL.

Danielson, B. and Crozier, A. (2004), "The art of closing archives: some aspects of centrally directed archives creation in the state administration of Sweden", Comma, Vol. 2004 No. 1, pp. 163-171.

Dryden, J. (2004), "What's in a word: the fuzziness of archival terminology”, Journal of Archival Organization, Vol. 2 Nos 1/2, pp. 147-151.

eGovernment Delegation (2013), “About the delegation”, available at: www.edelegationen.se/InEnglish/About-the-Delegation/Summary-of-the-remit/ (accessed 27 April 2014).

European Parliament and the Council (2003), "Directive on the re-use of public sector information (2003/98/EC)", Official Journal of the European Union, L 345/90, 31 December.

Ewald, F. (1997), "Arkivbildarbegreppet och proveniensprincipen under press [The concept of archive creator and the principle of provenance under pressure]", Arkiv Samhälle och Forskning, Vol. 3 No. 3.

Flen Municipality (2013), "Flens centralarkiv [The central archive of Flen]", available at: www. flen.se/sv/Turister-Besokare/Historia/Flens-Centralarkiv-/ (accessed 28 March 2014).

Föreningen Sambruk (2008), Business Development and Shared Use of Municipal e-Services The Swedish Association of Municipalities for Joint Development of e-Services, Sambruk, Sandviken.

Friberg, F. (2012), Dags för uppsats: vägledning för litteraturbaserade examensarbeten [Time for the Essay: A Guide to Literature-Based Theses], 2nd ed., Studentlitteratur, Lund.

Geijer, U., Lenberg, E. and Lövblad, H. (2013), Arkivlagen. En kommentar [The Archives Act. a Comment], Norstedts, Vanda. 
Gorman, G.E. and Clayton, P. (2004), Qualitative Research for the Information Professional, 2nd ed., Facet Publishing, London.

Gränström, C. (2000), Arkivlagen: bakgrund och kommentarer [The Archives Act: Background and Comments], 2nd ed., Norstedts juridik, Stockholm.

Gränström, C. (2004), “Arkivverksamhetens syften [The purpose of archive activities]”, in Abukhanfusa, K. and Riksarkivet (Eds), Handlingsoffentlighet utan handlingar?: rapport från ett seminarium i Stockholm den 7 mars 2003 [Freedom of information without records? Report from a Seminar, 7 March 2003, Stockholm], Riksarkivet, Stockholm.

Hörnfeldt, T. (1998), "The concept of record - on being digital”, in Abukhanfusa, K. (Ed.), The Concept of Record: Report from the Second Stockholm Conference on Archival Science and the Concept of Record, 30-31 May 1996, Riksarkivet, Stockholm.

International Council on Archives (2014), "Multilingual archival terminology", available at: www. ciscra.org/mat/termdb/term/210 (accessed 1 February 2014).

Jörwall, L., Lönnroth, L. and Nordström, G. (2012), Det globala minnet: nedslag i den internationella arkivhistorien [The Global Memory: Examples from the International History of Archives], Riksarkivet, Stockholm.

Kallberg, M. (2012), “Archivists 2.0: redefining the archivist's profession in the digital age”, Records Management Journal, Vol. 22 No. 2, pp. 98-115.

Kallberg, M. (2013), “The emperor's new clothes' recordkeeping in a new context”, Dissertation, Mittuniversitetet, Sundsvall, available at: http://miun.diva-portal.org/smash/record.jsf? pid= $\operatorname{diva} 2 \% 3 \mathrm{~A} 664496 \&$ dswid $=-5475$

Larsson, E. (2012), Måste jag diarieföra det här?: En handbok om regler och rutiner för ärenderegistrering [Do I Have to Register This?: A Handbook About Rules and Routines for Registering Cases], 2nd revised ed., SKL Kommentus media, Stockholm.

McKemmish, S. (2001), "Placing records continuum theory and practice", Archival Science, Vol. 1 No. 4, pp. 333-359.

McKemmish, S. (2005), Archives: Recordkeeping in Society, Centre for Information Studies, Charles Sturt University, Wagga Wagga.

Millar, L. (2010), Archives: Principles and Practices, Facet, London.

National Archives of Australia (2014), "Archives \& recordkeeping glossary”, available at: www. naa.gov.au/records-management/publications/glossary.aspx (accessed 25 April 2014).

Öberg, S. (2011), Mellanarkiv, slutarkiv och KoVIS - vad är skillnaden? [Middle Archive, Final Archive and Ko VIS - What is the Difference?], Vol. 4, Nyhetsbrev från Landstingsarkivet, Stockholm.

Pearce-Moses, R. and Baty, L.A. (2005), A Glossary of Archival and Records Terminology, Society of American Archivists, Chicago, IL.

PSI-utredningen (2014), SOU 2014:10 Ett steg vidare - nya regler och àtgärder för att främja vidareutnyttjande av handlingar [A Step Further - New Rules and Actions for Promoting Reclamation of Records], Fritzes, Stockholm.

R7 (2014), "Så här fungerar det [This is how it works]", available at: www.r7earkiv.se/fungera. html (accessed 28 March 2014).

Ridener, J. (2009), From Polders to Postmodernism a Concise History of Archival Theory, Litwin Books, Duluth, MN.

Riksarkivet (2008), "Rapport angående elektroniska arkiv (e-arkiv), bevarandeexemplar och system för bevarande - bevarande av elektroniska handlingar hos myndighet [Report 
regarding electronic archives (e-arkives), copies for preservation and system for preservation - perservation of electronic records at authority]", in Gäfvert, T. and Jarborn, E. (Eds), Riksarkivet, Stockholm.

Riksarkivet (2010a), Hanteringen av arkiv frän myndigheter som avvecklas [The Management of Archives From Discontinued Public Authorities], Riksarkivet, Stockholm.

Riksarkivet (2010b), "Rapport rörande enkätundersökning - myndigheters hantering av elektroniska handlingar [Report concerning survey - authorities' handling of electronic records]”, in Gäfvert, T. and Jarborn, E. (Eds), Riksarkivet, Stockholm.

Riksarkivet (2014a), "The e-archive and e-Diarium project, eARD”, available at: http://riksarkivet. se/Media/pdf-filer/Projekt/eARD_informationstext_eng.pdf (accessed 7 March 2014).

Riksarkivet (2014b), "Publicerade rapporter från eARD [published reports from eARD]", available at: https://riksarkivet.se/publicerade-rapporter-fran-eard (accessed 10 April 2014).

Riksarkivet (2014c), "Riksarkivet [The national archives]”, available at: http://riksarkivet.se/ startpage (accessed 17 March 2014).

Riksarkivet eARD (2013a), "Delprojekt 1 (DP1) inom e-arkiv och e-diarium (Begreppsdefinitioner) Ordlista [Subproject 1 within e-archive and e-diarium (Concept definitions) Glossary] Version 1:1", 14 January, Stockholm.

Riksarkivet eARD (2013b), "Paketstruktur Förvaltningsgemensam Specifikation (FGS) för paketstruktur för e-arkiv [Package structure management common specification (FGS) for packet structure for e-archives]", in Bredenberg, K. and Berggren, M. (Eds), Riksarkivet eARD, Stockholm.

Riksarkivet eARD (2013c), "Vägledning och funktionella krav [Guidelines and functional requirements]", in Tove, E. (Ed.), Stockholm.

Runardotter, M., Mörtberg, C. and Mirijamdotter, A. (2011), "The changing nature of archives: whose responsibility?”, Electronic Journal of E-Government (EJEG), Vol. 9 No. 1, pp. 68-78.

Sambruk (2011a), eSamhället och arkivet Elektroniskt Bevarande etapp 2 Slutrapport [eSociety and the Archive. Electronic Preservation Phase 2 Final Report], Sambruk, Sandviken.

Sambruk (2011b), Ordlista [Glossary], Sambruk, Sandviken.

Sambruk (2014), "Elektroniskt bevarande [Electronic preservation]", available at: www.sambruk. se/projektnatverk/avslutadeprojekt/elektronisktbevarande.4.6fa04b8c12eede97bff800033 68.html (accessed 10 April 2014).

Standéus, R. (2007), e-Arkivprojektet vid Skatteverket [The e-Archive Project at the Swedish Tax Authority], Malmö.

Svärd, P. (2011), "Transforming public administrations and challenges of information management", Archives and Manuscripts, Vol. 39 No. 2, pp. 96-118.

Sweden (1949), "Tryckfrihetsförordning [The freedom of the press act]", p. 105.

Sweden (1990), “Arkivlag [Archives act]”, p. 782.

Sweden (1991), “Arkivförordning [Archive ordinance]”, p. 446.

Sweden (2007), "Myndighetsförordning [Public authorities ordinance]”, p. 515.

Sweden (Näringsdepartementet) (2014), Uppdrag att utveckla och använda en förvaltningsgemensam tjänst för e-arkiv [Assignment to Develop and use an Administration Common Service for E-Archive], Sweden (Näringsdepartementet), Stockholm. 
Swedish Standards Institute (2001), SS-ISO 15489-1 Information and Documentation - Records Management Part 1: General, Swedish Standards Institute, Stockholm.

Walne, P.E. (2014), Dictionary of Archival Terminology (ICA Handbook), Vol. 7, Mèunchen, K.G. Saur, München.

Yoos, H. (1998), "Summary of discussions", in Abukhanfusa, K. (Ed.), The Concept of Record: Report From The Second Stockholm Conference on Archival Science and the Concept of Record, 30-31 May 1996, Riksarkivet, Stockholm.

New concept in Sweden

About the author

Ann-Sofie Klareld commenced as a PhD Student in February 2013 within the project Good Information Governance (GoInfo), at the Department of Archives and Computer Science, Mid Sweden University. She holds a Bachelor of Arts in Archives and Information Science and a Master of Arts in Ethnology. She has previously worked as an archivist and registrar for several years, primarily in the state and municipal sector. Her research interests include the (re)organization of mandates and responsibilities relating to archives and records in the context of e-government development. Ann-Sofie Klareld can be contacted at: annsofie.klareld@gmail.com

For instructions on how to order reprints of this article, please visit our website: www.emeraldgrouppublishing.com/licensing/reprints.htm Or contact us for further details: permissions@emeraldinsight.com 